Revista Mexicana de Economía y Finanzas Nueva Época

Volumen 14 Número 4, Octubre - Diciembre 2019, pp. 745-767

DOI: https://doi.org/10.21919/remef.v14i4.389

\title{
Social Weights and the Regional Allocation of Inter-Governmental Transfers
}

\author{
Raúl Alberto Ponce Rodríguez ${ }^{1}$ \\ Universidad Autónoma de Ciudad Juárez, México \\ Benito Alan Ponce Rodríguez ${ }^{2}$ \\ Universidad Autónoma de Ciudad Juárez, México \\ (Recepción: 8/abril/2019, aceptado: 13/julio/2019)
}

\section{Abstract}

We develop a theory and simulation analysis to calculate optimal transfers from the central government to state governments in Mexico. Our results are: First, our models show that the best predictor of intergovernmental transfers in Mexico is population density. Second, we provide estimates of optimal intergovernmental transfers to states in Mexico. Our analysis suggests using the inequality of income distribution in the social welfare function as an instrument of public policy and our estimates help to understand the advantages and disadvantages of the current transfer system. The main limitation of our work is that it does not consider political factors in the calculation of transfers. Our analysis is the first to develop estimates of intergovernmental transfers using Paretian parametric functions of regional income distribution and interregional preferences for local public spending. Our work proposes an alternative allocation of intergovernmental transfers that could improve the welfare associated with local public spending in Mexico. JEL Classification: H7, H77, O15, H21

Keywords: Intergovernmental transfers, fiscal federalism, income distribution, efficiency, heterogeneity of preferences

\section{Pesos Sociales y Asignación Regional de Transferencias Intergubernamentales}

\section{Resumen}

Desarrollamos una teoría y un análisis de simulación para calcular las transferencias óptimas de recursos del gobierno central a los gobiernos estatales en México. Nuestros resultados son: Primero, nuestros modelos muestran que el mejor predictor de las transferencias intergubernamentales en México es la densidad poblacional. Segundo, proporcionamos estimaciones sobre las transferencias intergubernamentales óptimas a los estados en México. Nuestro análisis sugiere utilizar la inequidad de la distribución del ingreso en la función de bienestar social como instrumento de política pública y nuestras estimaciones ayudan a entender las ventajas y desventajas del sistema actual de transferencias. La principal limitación de nuestro trabajo es que no considera factores políticos en el cálculo de las transferencias. Nuestro análisis es el primero en desarrollar estimaciones de las transferencias intergubernamentales al utilizar funciones paramétricas Paretianas de la distribución regional del ingreso y las preferencias inter-regionales por el gasto público local. Nuestro trabajo propone una asignación alternativa de transferencias

\footnotetext{
${ }^{1}$ Universidad Autónoma de Ciudad Juárez, Av. Universidad y Av. Heroico Colegio Militar S/N Zona Chamizal C.P. 32300, Ciudad Juárez, Chihuahua, México. Phone: 6883837, email: rponce@uacj.mx. ORCID: https://orcid.org/0000-0003-0851-2687

${ }^{2}$ Universidad Autónoma de Ciudad Juárez, Av. José de Jesús Macías Delgado, Núm. 18100 | Tel. (+52) 6882100 al 09. Ciudad Juárez, Chihuahua, México. email: alan.ponce@uacj.mx. ORCID: https://orcid.org/0000-0003-4550-2103

*Sin fuente de financiamiento declarada para el desarrollo de la investigación
} 


\section{Resumen}

intergubernamentales que podría mejorar el bienestar asociado con el gasto público local en México.

JEL Classification: J01, J23, J24, M51, 031

Keywords: entrepreneurship; global innovation index; human talent; search and matching with frictions

\section{Introduction}

Empirical evidence shows that the vast majority of central governments in modern economies use inter-governmental transfers (monetary transfers from the central government to subnational governments) to finance goods and services provided by subnational governments. Intergovernmental transfers are used in modern economies for different reasons: first, local public goods provided by subnational governments might show positive regional externalities. In the absence of intergovernmental transfers, local governments might not recognize the external benefits of local public goods and the provision of local public goods is not Pareto efficient. The central government can design a system of transfers to create incentives for local governments to provide Pareto efficient levels of local public goods (see Boadway 2007).

Second, intergovernmental transfers can be used to redistribute resources and reduce the inequality in the distribution of access to critical government services for individuals living in different regions of a country. Subnational governments might have different abilities to provide goods and services to their residents. This might lead to a problem of horizontal inequality in the access of residents of different localities to goods and services provided by sub-national governments such as public education, public security and health services (see Martinez and Sepulveda 2011). Therefore, a program of intergovernmental transfers can redistribute resources from high income to low income localities to improve the quality and access of critical services from the government in all regions of the country. Third, intergovernmental transfers can be explained as a mechanism to share revenue across different subnational governments (see Rao 2007) and to reduce failures of coordination that could lead to vertical and horizontal tax externalities (see Ponce and Medina 2018).

In Mexico, the provision of goods and services of sub-national governments is highly dependent of resources transferred by the central government to state governments. The evidence shows that, in 2014, the proportion of intergovernmental transfers in relation of total state public revenues is $84 \%$ (similar estimates are found for other years). According to a report of World Bank (2019), the total amount of intergovernmental transfers in Mexico is approximately 8.1 percent of GDP in 2017. In practice, Mexico uses intergovernmental transfers for different purposes: for instance, the fund of "participaciones" is a revenue sharing program financed by federal taxes aiming to reduce significant vertical imbalances (see the report by World Bank 2019). ${ }^{3}$ Intergovernmental transfers also include conditional transfers (through the fund of aportaciones) that finance specific projects in the areas of health, public security, etc., and discretionary transfers though specific agreements or convenios to finance the perceived priorities of policy makers in the central and state governments (see the report by World Bank 2019).

Given the importance of intergovernmental transfers in Mexico, it is relevant to ask: what should be the optimal distribution of inter-governmental transfers to state governments in Mexico? The objective of this paper is to develop a theoretical model to answer

\footnotetext{
${ }^{3} \mathrm{~A}$ vertical fiscal imbalance corresponds to the difference between the own revenues of a particular level of government and its expenditures.
} 
this question. We also develop a simulation analysis of the implied results of the theory to compare with the observed allocation of intergovernmental transfers in Mexico. Our analysis shows that the current system of allocation of intergovernmental transfers are poorly related with the regional inequality in the distribution of income and the regional heterogeneity of preferences of individuals for local public spending. However, most analysis on fiscal federalism, consider both, the regional distribution of income and the distribution of preferences, as important determinants of intergovernmental transfers. Hence, our analysis provides insights about advantages and shortcomings of the way intergovernmental transfers are currently allocated in Mexico. To see this, note that the first insight of our analysis shows that our model that considers a social welfare function in which all individuals of all regions receive the same weight in the social welfare function, provides a surprisingly good fit for the observed shares of transfers from the central government to states with our simulated results having a correlation of 0.9 with the observed shares of intergovernmental transfers received by states in Mexico.

Second, if the central government is concerned with the regional inequality of income then the implied shares of transfers to state governments are significantly different to the observed allocation of state transfers in Mexico. Altogether these findings suggest that the observed shares of intergovernmental transfers in Mexico are not fully incorporating the regional inequality of income. However, our estimates indeed consider the regional inequality of income in Mexico, and therefore, our estimates provide a complete set of estimates for transfers to states that could lead to a policy reform that improves the regional equity of public spending of state governments.

Third, we provide estimates of shares of intergovernmental transfers to state governments for the case in which policy is concerned about matching the provision of local public goods with the heterogeneity of preferences of individuals across regions in Mexico. For this case, we also provide exact estimates of the shares of resources that each state should receive and our analysis reveals opportunities for Pareto efficient improvements in the allocation of intergovernmental transfers to state governments in Mexico. In summary, our model identifies prescriptions of policy that could reform the way intergovernmental transfers are allocated in Mexico. Our policy prescriptions could lead to improvements of welfare in the Mexican economy related with a more effective subnational public spending.

The rest of the paper is structured as follows: section 2 provides a literature review. Section 3 introduces our theoretical model. Section 4 considers that the design of intergovernmental transfers seek to maximize a social welfare function that satisfies the properties of unanimity and symmetry in the allocation of social weights (all states receive the same social weight in the social welfare function). Section 5 estimates intergovernmental transfers for the case in which policymakers seek to reduce the regional inequality in the distribution of income. Section 6 considers social weights associated with the intensity of preferences for local public goods. Section 7 includes the description of the data and the simulation analysis that provides estimates of optimal shares of intergovernmental transfers to state governments. Section 8 presents the results of our simulations. Section 9 concludes.

\section{Literature Review}

The literature on public economics on intergovernmental transfers can be classified by normative theories (that seek to study how policies should be designed and implemented) and positive theories (that study how polices are designed and implemented). One influential contribution on public finance is the median voter theory which postulates that government spending and taxation are determined by politicians that seek to win elections see Meltzer and Richard (1981). In this case, a central and sub-national governments design the ideal policy of the median voter on government spending and taxation because that is the policy that maximizes votes in the election. More recently, Hettich 
and Winer (2005) criticize the median voter model by pointing out that this model can not explain the complexity of modern tax systems and the multi-dimensional aspects of government spending. They propose a probabilistic voting model that predicts that policy makers deign tax and spending policies to please different groups in the society. Hence, governments select the ideal policy of the average voter or a weighted average voter in the electorate. Some applications to the theory of fiscal federalism from models with electoral concerns include the analysis of Besley and Coate (2003) who study the role of local and national legislatures in determining taxing and spending decisions of central and subnational governments and Lockwood (2008) who studies the role of lobbying in explaining the structure of governments in a federalist economy (for a survey of the political economy of fiscal federalism see Lockwood 2015). Recent empirical analysis, see Ponce, et al (2018) and Hankla, Martinez-Vazquez and Ponce-Rodriguez (2019) show worldwide robust evidence that elections and political institutions are important determinants of government spending in federations.

On the normative theory of fiscal public finance, the landmark theories of optimal taxation and optimal public spending consider that policy makers should design public policies to maximize a social welfare function which represents the collective welfare of society. While designing policy, policy makers, might assign weights to the welfare of individuals in the social welfare function. These social weights might represent well deserving objectives that policy makers want to achieve such as an equitable allocation of resources or concerns about the efficiency in the allocation of resources (see Atkinson and Stiglitz 1972, 1976 and more recently Saez and Stantcheva 2016). The normative analysis has emphasized that intergovernmental transfers should also be used to redistribute resources and reduce the inequality in the distribution of access to critical government services for individuals living in different regions of a country (see Boadway 2007). Subnational governments might have different abilities to provide goods and services to their residents. This might lead to a problem of horizontal inequality in the access of residents of different localities to goods and services provided by sub-national governments such as public education, public security and health services (see Martinez and Sepulveda 2011). Others have pointed out that intergovernmental transfers should be assigned to achieve an efficient allocation of resources, see Boadway and Shah (2007). Intergovernmental transfers can also be explained as a mechanism to share revenue across different subnational governments (see Rao 2007) and to reduce failures of coordination that could lead to vertical and horizontal tax externalities (see Ponce-Rodriguez and Medina 2018).

Our analysis is a normative theory that allows to identify prescriptions of policy design by identifying optimal allocations for intergovernmental transfers. Our paper is different from the literature because we study the role of social weights in the social welfare function as a determinant of spending and tax policy design. The determination of weights takes into consideration the objectives of policy design of policy makers. Hence, the inter-regional allocation of weights might reflect priorities related with anti-poverty programs, concerns with the regional distribution of income and the efficiency in the allocation of resources. Hence, our theory contributes to the literature by considering specific Paretian regional distribution functions of social weights in the social welfare function and characterizing the optimal amount of intergovernmental transfers to states when policy makers are concerned about the regional inequality of income and the regional distribution of heterogeneity of preferences of individuals for local public spending. ${ }^{4}$

In addition, in this paper we develop a simulation analysis of the implied results our theory to compare with the observed allocation of intergovernmental transfers in Mexico.

\footnotetext{
${ }^{4}$ The regional heterogeneity of preferences of individuals for local public goods determine the regional distribution of social marginal benefits from local public spending and social marginal costs from taxation that finances government spending. Thus, in the context of a federation, a government that incorporates the heterogeneity of preferences might lead to an efficient allocation of local public spending.
} 
This comparison provides insights about advantages and shortcomings of the way intergovernmental transfers are currently allocated in Mexico. In particular, our analysis shows that the current system of allocation of intergovernmental transfers are poorly related with the regional inequality in the distribution of income and the regional heterogeneity of preferences of individuals for local public spending. However, most analysis on fiscal federalism, consider both, the regional distribution of income and the distribution of preferences, as important determinants of intergovernmental transfers. Hence, our analysis provides insights about advantages and shortcomings of the way intergovernmental transfers are currently allocated in Mexico.

\section{The Model}

The preferences and budget constraint of a resident living in locality $i=1,2 \ldots I$ are characterized by the utility function of a representative household living in the locality, $\mu_{i}=x_{i}+\beta_{i} \ln \left(g_{i}\right)$, where $x_{i}$ is a private good, $g_{i}$ is a public good provided in locality i and $\beta_{i}>0$ is a parameter measuring the intensity of preferences for the public good. The budget constraint of the representative household in locality i is $x_{i}=e_{i}\left(1-\tau_{i}\right)$ where $e_{i}$ is an endowment and $\tau_{i}$ is a proportional income tax. The indirect utility of this individual is given by $v_{i}\left(e_{i}, \tau_{i}, g_{i}\right)=e_{i}\left(1-\tau_{i}\right)+\beta_{i} \ln \left(g_{i}\right)$. Population in each of the localities is given by $N_{i} \forall i$.

We consider an economy fiscally centralized in which there is a central government and I local governments. Spending and taxing decisions are determined by the central government while local governments are simple administrators of the provision of the public good on their localities. The central government collects tax revenue from all regions of the country by imposing a uniform proportional income tax $\tau_{i}=\tau \quad \forall i$ and determines intergovernmental transfers to finance local public goods in all regions. Hence $T_{i}=g_{i} \quad \forall i$ where $T_{i} \quad \forall i$ is the intergovernmental transfer allocated from the central government to the local government of region $\mathrm{i}$.

The central government selects $\left\{T_{i}\right\}_{i=1}^{I}, \tau \quad \forall i$ to maximize a nationwide social welfare function $\Psi=\sum_{i=1}^{I} \Psi_{i}$, which is the sum of utilities of residents of each region and $\Psi_{i}=N_{i} v_{i}\left(e_{i}, \tau_{i}, T_{i}\right)$ is the social welfare of region i. In designing policy, the central government considers the nationwide distribution of social benefits of local public goods and the nationwide social welfare costs associated with taxation. The government faces the following trade-offs in the design of intergovernmental transfers: On the one hand, a marginal increase in the income tax implemented by the central government reduces private consumption of all residents in the economy. This constitutes a social marginal cost.

On the other hand, the government collects tax revenue and redistributes resources in the economy through intergovernmental transfers that finance local public goods in the economy. This is the social marginal benefit. At equilibrium, the optimal level of intergovernmental transfers in locality $\mathrm{i}$ is where the social marginal benefit of increasing local public spending in locality $\mathrm{i}$ is equal to the social marginal costs of taxation. The other trade-off for policy design is that the central government allocates resources through intergovernmental transfers taking into account that $1 \$$ allocated in locality i has an opportunity cost equivalent to the marginal benefits of local public goods in neighbour localities.

Hence the problem of tax and intergovernmental transfer policy design is given by:

$$
\begin{aligned}
& \operatorname{Max}_{\left\{T_{i}\right\}_{i=1}^{I}, \tau} \quad \Psi=\sum_{i=1}^{I} \Phi_{i} \Psi_{i} \\
& \text { s.t: } \quad \text { i) } \Psi_{i}=N_{i} v_{i}\left(e_{i}, \tau_{i}, g_{i}\right)
\end{aligned}
$$




$$
\text { ii) } \quad \sum_{i=1}^{I} T_{i}=\tau \sum_{i=1}^{I} N_{i} e_{i}
$$

$$
\text { iii) } \quad T_{i}=g_{i} \quad \forall i
$$

Equation (1) is the nationwide social welfare which is the sum of the weighted social welfare functions of each localities $\Psi_{i} \forall i$. In equation (1), $\Phi_{i} \geq 0$ is the social marginal utility of the representative household living in locality $i$. This social weight shows the importance of a household living in locality $\mathrm{i}$ with endowment $e_{i}$ in the society, and therefore, it might reflect concerns (or tastes) of the policy maker over inter-regional income inequality and the inter-regional heterogeneity of preference for local public goods. Equation (3) is the budget constraint of the central government, the left hand side is the total amount of intergovernmental transfers allocated to all subnational governments and the right hand side are the public revenues of the central government. Equation (4) says that the intergovernmental transfers of the central government finances local public goods in all localities.

In what follows, we characterize the equilibrium level of inter-governmental transfers of the central government to subnational governments $i=1,2 \ldots I$.

Proposition 1. The optimal allocation of inter-governmental transfers to subnational government in locality $i$ is given by

$$
T_{i}^{*}=\Phi_{i} N_{i} \beta_{i}\left\{\frac{\sum_{i=1}^{I} N_{i} e_{i}}{\sum_{i=1}^{I} \Phi_{i} N_{i} e_{i}}\right\} \quad \forall i
$$

\section{Proof.}

See appendix 1.

Proposition 1 says that the optimal allocation of inter-governmental transfers that finances local public spending in locality i depends positively on the country's aggregate income, $\sum_{i=1}^{I} N_{i} e_{i}$, and the marginal social utility of local public spending on locality i, $\Phi_{i} N_{i} \beta_{i}$, and negatively on the country's weighted aggregate income $\sum_{i=1}^{I} \Phi_{i} N_{i} e_{i}$. The higher the country's aggregate income the higher the tax revenue of the central government and the higher the intergovernmental transfers that finance public spending in all localities (including locality i). The higher the weighted aggregate income, $\sum_{i=1}^{I} \Phi_{i} N_{i} e_{i}$, the higher the social marginal costs from income taxation and the lower is public spending in the whole country (including locality i). The higher the social marginal utility of public spending on locality i, $\Phi_{i} N_{i} \beta_{i}$, the higher the social marginal benefits of spending in the locality and the higher is $T_{i}^{*}$. Note, that increases in the social marginal utility of residents of locality $i$ in the social welfare of the central government, $\Phi_{i}$, in the size of population of the locality $i, N_{i}$, and the intensity of preferences for public goods, $\beta_{i}$, lead to increases in the marginal social utility of public spending on locality $i$, and consequently, in increases in intergovernmental transfers in the locality.

\section{Social Weights and the Regional Allocation of Inter-Governmental Transfers}

In this section, we analyse how the allocation of social weights determine the regional distribution of inter-governmental transfers and local public spending. The allocation of social weights in the social welfare function might be explained by preferences (or concerns) of policy makers over regional inequality, the distribution of regional preferences of citizens over local public goods, the regional distribution of population, etc. Even other incentives such as electoral concerns and political ideology might affect the allocation of 
social weights, the regional distribution of intergovernmental transfers and the regional distribution of public spending.

In what follows, proposition 2 characterizes our benchmark outcome in which all households of all localities receive the same weight in the social welfare function of the central government. That is, $\Phi_{i}=\Phi_{j}=\Phi \forall i \neq j$. This case reflects a symmetry in the way households, living in different regions, are treated by the central government. In this case, the social welfare function of the central government is considered to satisfy the unanimity and symmety properties in which all households have the same marginal social utility. ${ }^{5}$

Proposition 2. If $\Phi_{i}=\Phi_{j}=\Phi \quad \forall i \neq j$ then the optimal allocation of inter-governmental transfers is given by

$$
T_{i}^{*}=N_{i} \beta_{i} \quad \forall i
$$

\section{Proof.}

Result follows trivially from proposition 1.

Proposition 2 says that if the central government assigns the same weight to the welfare of all individuals in the economy in the social welfare function from then the optimal allocation of inter-governmental transfers that finances local public spending in all localities depend only on the regional distribution of social marginal benefits of local spending in each locality, $N_{i} \beta_{i}$. That is to say, localities with higher than average marginal utility of government spending should receive higher than average intergovernmental transfers. In this economy, localities with higher than average population and higher than average preferences for local public goods should receive higher than average transfers and the size of local public spending should also be higher than the nationwide average.

\section{Inter-Regional Income Inequality, Social Weights with Equity Concerns and Government Spending}

The policy maker might be concerned about the inter-regional inequality of income. This might be an issue of main concern for policy design because different regions might have different incomes and therefore different capacities to provide local public goods such as public infrastructure, education, health services and other important tasks in which the government is involved. Hence, wealthy regions might be able to afford essential public spending that affects positively the welfare of their residents while poor regions would be constrained to have access to local resources to finance public spending. This, in turn, will lead to an unequal distribution of local public spending and welfare of residents in the economy. For this reason, a policy maker might assign priorities on the regional allocation of inter-governmental transfers to design an equalization transfer policy in which wealthy regions redistribute income to poor regions.

More relevant for our analysis, is that the policy maker in the central government could have a taste for the regional inequality of income. This "taste" corresponds to the personal view of the policy maker of the central government over the issue of the regional inequality of income in the economy. For instance, the policy maker in the central government might believe that one of the objectives of designing intergovernmental transfers is to maximize the redistribution of welfare of individuals living in different regions. Such a personal view of the policy maker in the central government would imply a very particular set of social weights in the social welfare function in which localities with low income receive a high social weight in the social welfare function. In this case, the regional equitable distribution of income would be a clear objective in the allocation of intergovernmental transfers.

\footnotetext{
${ }^{5}$ This social welfare function is said to be symmetric because all households have the same marginal social utility in the social welfare function.
} 
One way to do so, is to assign specific weights to the regional distribution of marginal benefits of public spending. To do so, a policy maker could assign weights according to a Paretian distribution of income in which localities with low income might be assigned a high social weight in the social welfare function (see figure 1). In particular, the policy maker might assign weights that are inversely related to income in the locality. To characterize such possibility, we define $e_{i \min }=\operatorname{Min}\left\{e_{1}, e_{2} \ldots \ldots e_{I}\right\}$ therefore $e_{i m i n}$ represents the lowest income in the economy. The allocation of social weights in the social welfare function of the government motivated by inter-regional equity concerns is given as follows (see figure 1):

$$
\Phi_{i}=\left\{\begin{array}{cc}
\frac{e_{i \min }}{e_{i}} & \forall e_{i} \geq e_{i m i n} \\
0 & \forall e_{i}<e_{i m i n}
\end{array}\right.
$$

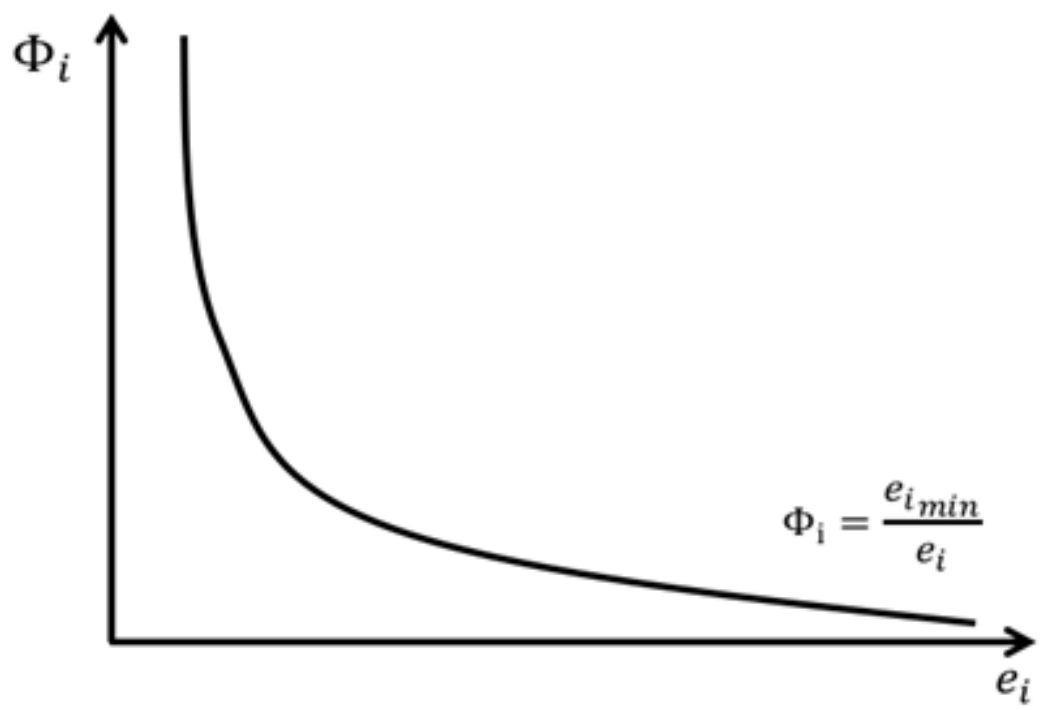

Figure 1. Paretian Distribution of Income

In condition (7), the policy maker assigns weights that are inversely related to income in the locality. Those localities with lower than average income have a social marginal utility (a social weight $\Phi_{i}$ ) higher than the average nationwide social marginal utility in the welfare function of the central government. Proposition 3 characterizes the distribution of intergovernmental transfers for the case policy design seeks to reduce the regional inequality of income.

Proposition 3. If the allocation of social weights is determined by equity concerns about the inter-regional distribution of income such that

$$
\Phi_{i}=\left\{\begin{array}{cc}
\frac{e_{i \min }}{e_{i}} & \forall e_{i} \geq e_{i m i n} \\
0 & \forall e_{i}<e_{i m i n}
\end{array}\right.
$$

Then the optimal allocation of inter-governmental transfers is denoted by $T_{i P}^{*}$ such that

$$
T_{i P}^{*}=N_{i} \beta_{i}\left\{\frac{E_{f}\left(e_{i}\right)}{e_{i}}\right\} \quad \forall i
$$

Where $E_{f}\left(e_{i}\right)=\sum_{i=1}^{I} f_{i} e_{i}$ is a weighted average of per capita income in locality $i$, and $f_{i}$ is the density of population in locality $i$ over the nationwide 
population such that

$$
f_{i} \in(0,1]: f_{i}=\frac{N_{i}}{\sum_{i=1}^{I} N_{i}} \wedge \sum_{i=1}^{I} f_{i}=1
$$

Proof.

See the appendix.

If the policy maker is concerned with the interregional inequality of income then the allocation of transfers for locality i depend on the aggregate intensity of preferences in locality $i, N_{i} \beta_{i}$, which in turn depends positively on the population of the locality, $N_{i}$, and the intensity of preferences of locality i over local public goods $\beta_{i}$. The transfer in each locality also depends positively on the relative measure of weighted income in the country and the income of locality i, $\frac{E_{f}\left(e_{i}\right)}{e_{i}}$, the higher the income in the locality i, in relation of the weighted nationwide average income, the lower the transfer in the locality.

Proposition 4 makes a comparative analysis of the distribution of transfers to locality i for the case in which the social weights reflect that the policy maker assigns the same social weight to all households, that is $T_{i}^{*}$, and for the case in which the policy maker has concerns about an equitable inter-regional allocation of resources in the country, $T_{i P}^{*}$.

Proposition 4. If the allocation of social weights is determined by an InterRegional Paretian distribution of income given by

$$
\Phi_{i}=\left\{\begin{array}{cc}
\frac{e_{i m i n}}{e_{i}} & \forall e_{i} \geq e_{i m i n} \\
0 & \forall e_{i}<e_{i m i n}
\end{array}\right.
$$

And if a locality $i$ satisfies

$$
e_{i} \leq E_{f}\left(e_{i}\right) \quad \text { then } \quad T_{i P}^{*} \geq T_{i}^{*}
$$

Proof.

This outcome follows trivially from propositions one and three.

Proposition 4 shows that if the allocation of social weights in policy design is not trivial. In particular, proposition 4 shows that if the policy maker is concerned about the inter-regional inequality of welfare of citizens then those localities with incomes that are lower to the socially weighted income $E_{f}\left(e_{i}\right)$ will receive higher transfers relative the situation in which all households have the same inter-regional social weight in the social welfare function, that is to say, if $e_{i} \leq E_{f}\left(e_{i}\right)$ then $T_{i P}^{*} \geq T_{i}^{*}$.

\section{Social Weights According to the Inter-Regional Distribution of Preferences and Intergovernmental Transfers}

Policy makers might have preferences (or might be concerned) about the inter-regional heterogeneity of preferences. This might be an issue of main concern for policy makers because different regions might have different intensities of preferences for local public goods. Optimal inter-governmental transfers are required to recognize the regional intensity of preferences for local public spending. To see this, note that localities with residents with higher than average marginal utilities from public spending (in our model, localities with higher than average values of $\beta_{i}$ ) will also have higher than average social marginal benefits from public spending. An optimal allocation of intergovernmental transfers requires that the higher is the marginal utility of public spending in the locality the higher should be the transfer to that locality, otherwise, local public spending would be sub-optimal. 
As we mentioned before, also relevant for our analysis is that the policy maker in the central government could have a taste for the heterogeneity of preferences of individuals for subnational spending. This "taste" corresponds to the personal view of the policy maker of the central government over the issue of the heterogeneity of preferences for subnational public spending in the economy. For instance, the policy maker in the central government might believe that the provision of public goods should be uniform across localities. Such a personal view of the policy maker in the central government would imply a very particular set of social weights in the social welfare function, however, such prescription of policy might not be socially optimal for the general case of the problem of the allocation of intergovernmental transfers.

Another possibility is that the policy maker wants to make the most efficient decisions in designing policy in the central government. Therefore, localities with high social marginal benefits from public spending could receive a high social weigh in the social welfare function. In this case, maximizing the regional net fiscal incidence of public goods (the net gains from government intervention) would be a clear objective in the allocation of intergovernmental transfers. The net fiscal incidence reflects the society's surplus from government intervention and recognizes the next economic tradeoff: on the one hand, a marginal increase in the income tax implemented by the central government reduces private consumption of all residents in the economy. This constitutes a social marginal cost. On the other hand, the government collects tax revenue and redistributes resources in the economy through intergovernmental transfers that finances local public goods in the economy. This is the social marginal benefit.

Hence, the net fiscal incidence is the net benefit-cost analysis from government intervention and represents the society's economic surplus (the sum of the consumer's and producer's surplus). By assigning social weights to the social welfare function, the policy maker is assigning weights to the net fiscal incidence of localities. Therefore, different weights to the net fiscal incidence of government intervention in each locality will lead to different levels of nationwide social welfare. For instance, if the policy maker assigns a high weight to localities with high net fiscal incidence then the nationwide welfare would be higher relative the alternative in which the policy maker assigns a high weight to localities with low net fiscal incidence.

Taking into account the regional distribution of net fiscal incidence of government intervention, policy makers can assign weights that are positively related with the intensity of preferences in each locality, that is to say, localities with high net fiscal incidence from local public goods should be assigned a high social weight in the social welfare function (see equation 10). To characterize such possibility, we define the locality with the highest parameter of intensity of preferences for public spending by $\beta_{i_{\max }}=\operatorname{Max}\left\{\beta_{1}, \beta_{2} \ldots \ldots \beta_{I}\right\}$. In this case, the allocation of weights for each locality $\Phi_{i}$ satisfies the following:

$$
\Phi_{i}=\left\{\begin{aligned}
\frac{\beta_{i}}{\beta_{i_{\max }}} & \forall \beta_{i} \leq \beta_{i_{\max }} \\
0 & \forall \beta_{i}>\beta_{i_{\max }}
\end{aligned}\right.
$$

We also define, $E_{h}\left(\beta_{i}\right)=\sum_{i=1}^{I} h_{i} \beta_{i}$, as the nationwide weighted average of the parameter of intensity of preferences $\beta_{i}$ and $h_{i}\left(e_{i}\right)$ as the share of income in locality i over the nationwide income, satisfying:

$$
h_{i}\left(e_{i}\right) \in(0,1]: h_{i}\left(e_{i}\right)=\frac{N_{i} e_{i}}{\sum_{i=1}^{I} N_{i} e_{i}} \wedge \sum_{i=1}^{I} h_{i}\left(e_{i}\right)=1
$$

In what follows, proposition 5 characterizes the size of inter-governmental transfers $T_{i \beta}^{*}$ for the case in which social weights are assigned to incorporate the heterogeneity of 
preferences over local public spending and proposition 6 compares $T_{i \beta}^{*}$ with the case in which the policy maker assigns the same social weight to all households, that is, $T_{i}^{*}$.

Proposition 5. If the allocation of social weights is determined by an interregional Paretian distribution of preferences given by

$$
\Phi_{i}=\left\{\begin{array}{cl}
\frac{\beta_{i}}{\beta_{i_{\max }}} & \forall \beta_{i} \leq \beta_{i_{\max }} \\
0 & \forall \beta_{i}>\beta_{i_{\max }}
\end{array}\right.
$$

Then the optimal allocation of inter-governmental transfers is denoted by $T_{i \beta}^{*}$ such that

$$
T_{i \beta}^{*}=N_{i} \beta_{i}\left\{\frac{\beta_{i}}{E_{h}\left(\beta_{i}\right)}\right\} \quad \forall i
$$

Where $E_{h}\left(\beta_{i}\right)=\sum_{i=1}^{I} h_{i} \beta_{i}$, is the nationwide weighted average of the parameter of intensity of preferences for localities and

$$
h_{i}\left(e_{i}\right) \in(0,1]: h_{i}\left(e_{i}\right)=\frac{N_{i} e_{i}}{\sum_{i=1}^{I} N_{i} e_{i}} \wedge \sum_{i=1}^{I} h_{i}\left(e_{i}\right)=1
$$

\section{Proof.}

See the appendix.

Proposition 5, says that for the case in which the inter-regional heterogeneity of preferences for local public goods determines the allocation of social weights $\Phi_{i}$, the distribution of inter-governmental transfers $T_{i \beta}^{*}$ depends positively on the aggregate intensity of preferences in locality i, $N_{i} \beta_{i}$, and on the ratio of the parameter of intensity of preferences of locality $\mathrm{i}$ in relation to the nationwide average intensity of preferences in the economy given by $\frac{\beta_{i}}{E_{h}\left(\beta_{i}\right)}$.

Proposition 6 compares $T_{i \beta}^{*}$ with the case in which the policy maker assigns the same social weight to all households, that is, $T_{i}^{*}$.

Proposition 6. If the allocation of social weights is determined by an Interregional Paretian distribution of preferences given by

$$
\Phi_{i}=\left\{\begin{array}{cl}
\frac{\beta_{i}}{\beta_{i_{\max }}} & \forall \beta_{i} \leq \beta_{i_{\max }} \\
0 & \forall \beta_{i}>\beta_{i_{\max }}
\end{array}\right.
$$

And if a locality $i$ satisfies

$$
\beta_{i} \geq E_{h}\left(\beta_{i}\right) \quad \text { then } T_{i \beta}^{*} \geq T_{i}^{*}
$$

\section{Proof.}

This outcome follows by comparing $T_{i \beta}^{*}$ from proposition 5 and $T_{i}^{*}$ from proposition 2 .

Proposition 6 shows that if the policy maker is concerned about the inter-regional heterogeneity of preferences for local public spending then those localities with values of $\beta_{i}$ that are higher to the weighted value of the intensity of preferences for local public spending $E_{h}\left(\beta_{i}\right)=\sum_{i=1}^{I} h_{i} \beta_{i}$ will receive higher transfers relative the situation in which all households have the same inter-regional social weight in the social welfare function, that is to say, if $\beta_{i} \geq E_{h}\left(\beta_{i}\right)$ then $T_{i \beta}^{*} \geq T_{i}^{*}$. 


\section{Simulations and Estimates of Optimal Shares of Inter-Governmental Transfers}

Our theory makes predictions over the size and regional distribution of intergovernmental transfers. In particular, table 1 shows predictions of our theory for the optimal allocation of inter-governmental transfers (see column B of table 1) and its implied shares of intergovernmental transfers in relation to the total amount of resources devoted from the central government to state governments (see column $\mathrm{C}$ of table 1). The shares of intergovernmental transfers are defined as follows, consider $T_{i}^{*}$ as the amount of inter-governmental transfers allocated by the central government to the government of state $i$. The share of inter-governmental transfers in the state is given by $s_{i}^{*}=\frac{T_{i}^{*}}{\sum_{i=1}^{I} T_{i}^{*}}$ where $\sum_{i=1}^{I} T_{i}^{*}$ is the total amount of resources devoted from the central government to state governments. ${ }^{6}$

Based on our theoretical model, we provide estimates for the size and regional distribution of shares of intergovernmental transfers to state governments for the cases in which the central government is concerned about the regional inequality in the distribution of income and the regional heterogeneity of preferences for local public goods. We also provide estimates for the case in which the social welfare function satisfies the properties of unanimity and symmetry (all social weights are the same).

For the analysis of simulation, we use data for intergovernmental transfers, $T_{i}^{*}$, as the sum of "participaciones" and "aportaciones" from the central government to state governments for year 2014, the state population in locality i for year 2014 (which is $N_{i}$ ), the real state gross domestic product of locality i for year 2014 (which in our model is $e_{i}$ ), and for the parameter of intensity of preferences we use the proportion of women with superior education for year 2014 (women with a college degree). Empirical evidence shows that the characteristics of population in the locality matter to determine the demand of local public spending. In particular, the larger the proportion of women and the larger the education of residents the higher is the demand for public spending, see Ferris (1983), Bergstrom, Rubinfeld and Perry Shapiro (1982), Holsey and Borcherding (1997), among many others. Hence we use the proportion of women with a college degree in state i as a proxi of taste for goods and services provided by the state government. The higher the proportion of women with college degree the higher the intensity of preferences for goods and services from the government and the higher the demand for subnational public spending. The source of our data is Instituto Nacional de Estadistica, Geografia e Informatica (INEGI).

\footnotetext{
${ }^{6}$ It is worth mentioning that there is not a single formula for the allocation of the total amount of intergovernmental transfers due to the design of the fund of "participaciones" is different from the program of "aportaciones. In practice, intergovernmental transfers are used in Mexico for different purposes: for instance, the fund of "participaciones" is a revenue sharing program financed by federal taxes. According to a report from the Centro de Estudios de las Finanzas Publicas (2017), the general fund of "participaciones" uses a linear weighted formula to distribute resources to states that takes into consideration the growth of the general fund of "participaciones", the evolution of gross domestic product of each locality over time, and the evolution of tax revenue collection over time in each locality. It is important to recall that Intergovernmental transfers can also be discretionary transfers though specific agreements or convenios to finance the perceived priorities of policy makers in the central and state governments and therefore these funds are allocated in a discretionary form.
} 
Table 1. Optimal Inter-Governmental Transfers and Optimal Shares of

\begin{tabular}{|c|c|c|c|}
\hline Principles of Policy Design & $\begin{array}{l}\text { Social Weights } \\
\text { (A) }\end{array}$ & $\begin{array}{l}\text { Optimal Transfers } \\
\text { and Government } \\
\text { Spending, } T_{i}^{*} \\
\text { (B) }\end{array}$ & $\begin{array}{c}\text { Shares of Inter- } \\
\text { Governmental } \\
\text { Transfers, } \\
s_{i}^{*}=\frac{T_{i}^{*}}{\sum_{i=1}^{I} T_{i}^{*}} \\
\text { (C) }\end{array}$ \\
\hline $\begin{array}{c}\text { Unanimity and } \\
\text { Symmetry } \\
\text { (equal weights) }\end{array}$ & $\Phi_{i}=\Phi_{j}=\Phi \quad \forall i \neq j$ & $T_{i}^{*}=N_{i} \beta_{i}$ & $s_{i}^{*}=\frac{N_{i} \beta_{i}}{\sum_{i=1}^{N} N_{i} \beta_{i}}$ \\
\hline $\begin{array}{l}\text { Regional } \\
\text { Inequality of } \\
\text { Income }\end{array}$ & $\begin{aligned} & \frac{e_{i \min }}{e_{i}} \forall e_{i} \geq e_{i \min } \\
& 0 \forall e_{i}<e_{i \min } \\
&\end{aligned}$ & $T_{i P}^{*}=\frac{N_{i} \beta_{i} E_{f}\left(e_{i}\right)}{e_{i}}$ & $s_{i P}^{*}=\frac{\frac{N_{i} \beta_{i}}{e_{i}}}{\sum_{i=1}^{I} \frac{N_{i} \beta_{i}}{e_{i}}}$ \\
\hline $\begin{array}{l}\text { Regional } \\
\text { Heterogeneity } \\
\text { of Preferences }\end{array}$ & $\Phi_{i}=\left\{\begin{array}{cc}\frac{\beta_{i}}{\beta_{i_{\max }}} & \forall \beta_{i} \leq \beta_{i_{\max }} \\
0 & \forall \beta_{i}>\beta_{i_{\max }}\end{array}\right.$ & $T_{i \beta}^{*}=\frac{N_{i}\left(\beta_{i}\right)^{2}}{E_{h}\left(\beta_{i}\right)}$ & $s_{i \beta}^{*}=\frac{N_{i}\left(\beta_{i}\right)^{2}}{\sum_{i=1}^{I} N_{i}\left(\beta_{i}\right)^{2}}$ \\
\hline
\end{tabular}

In what follows, figure two shows the distributional allocation of state gross domestic product for Mexico for year 2014, figure three the state distributions of regional heterogeneity of preferences for year 2014, and figure four the state population for year 2014.

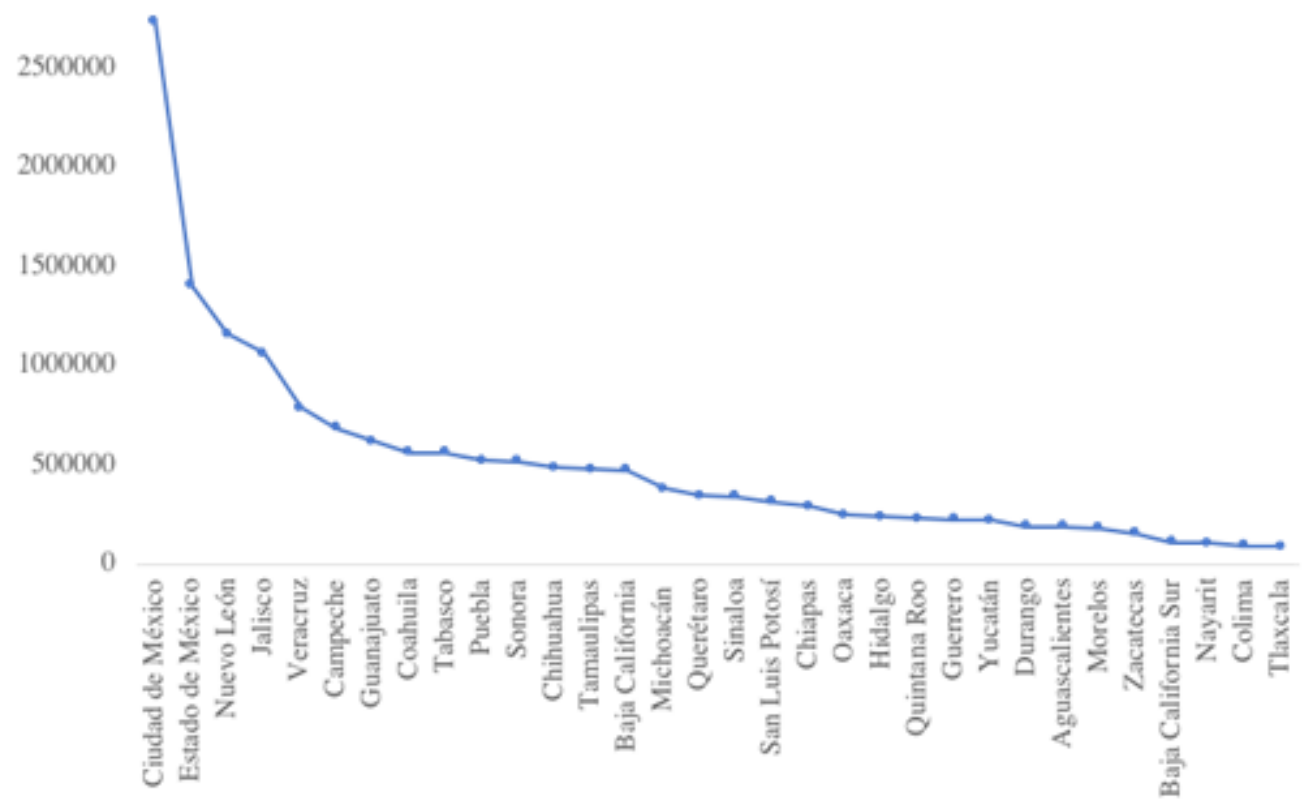

Figure 2. State Gross Domestic Product in Mexico, 2014 (Millions of pesos). 


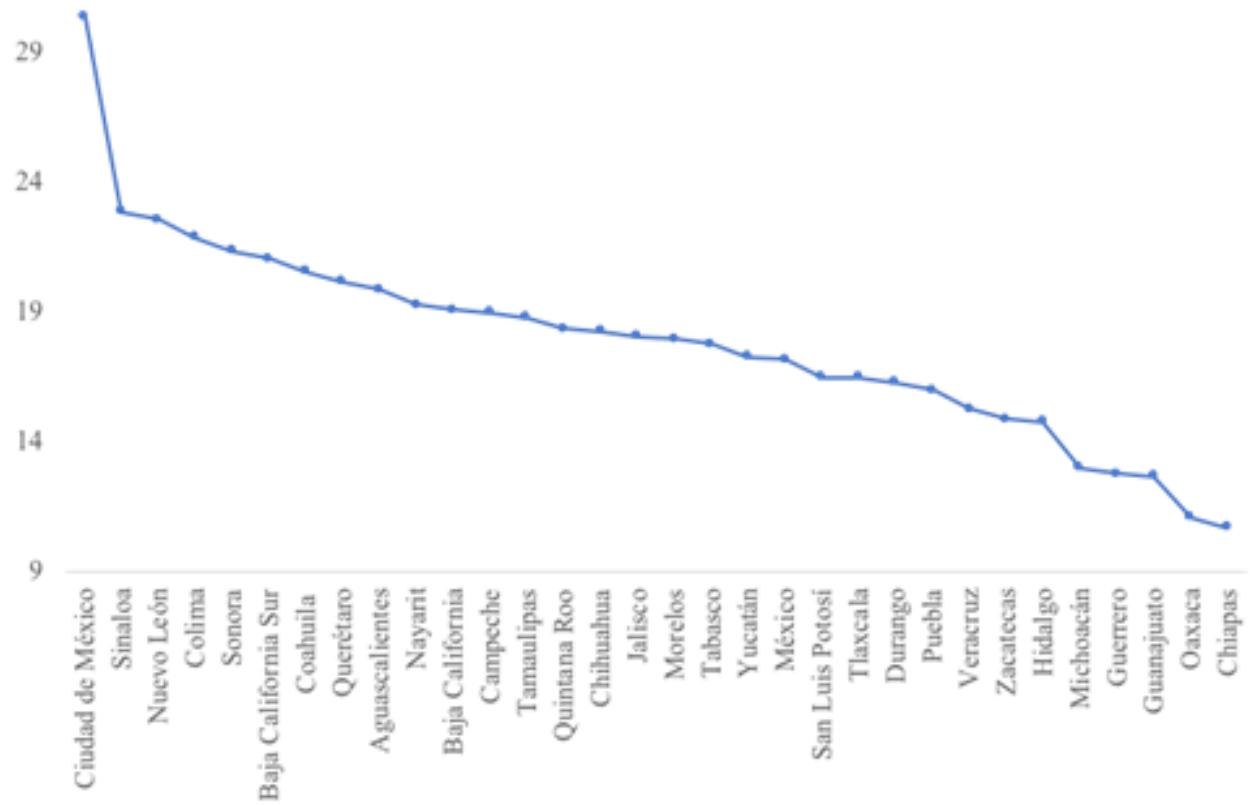

Figure 3. Percentage of Women With College Education, 2014.

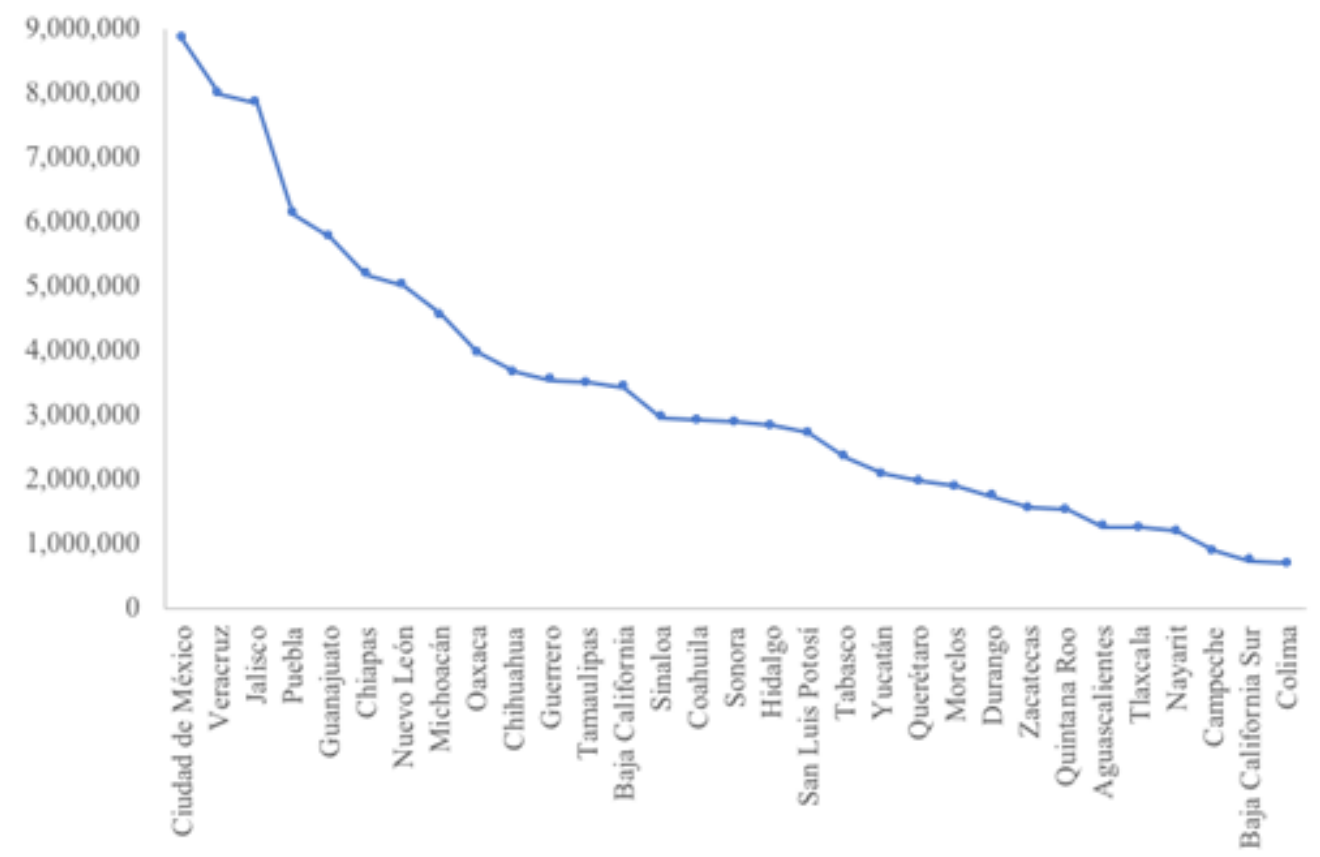

Figure 4. Percentage of Women With College Education, 2014. 


\section{Results}

In this section, we present the results of our estimations based on our theoretical model. In the appendix we show a summary of all of our simulations (see table 5). Figure 5 and 6 show the observed share of inter-governmental transfers and the estimated shares of intergovernmental transfers for the case in which policy makers use social weights given by $\Phi_{i}=\Phi_{j}=\Phi \forall i \neq j$. In this case, the social welfare function of the central government is considered to satisfy the unanimity and symmetric properties in which all households have the same marginal social utility. Our estimates of the shares of inter-governmental transfers are given by $s_{i}^{*}=\frac{N_{i} \beta_{i}}{\sum_{i=1}^{I} N_{i} \beta_{i}}$ (see table 1$)$. As figure 6 shows, the estimates from the theoretical model are surprisingly close to the observed intergovernmental transfers received by states in 2014. The correlation between the real shares and our estimates assuming weights of the social welfare reflecting the principles of unanimity and symmetry is 0.9. However, we estimate the shares of intergovernmental transfers using only the regional density of population and assuming that all individuals in all regions have the same preferences for public spending. These estimates have a correlation with the observed data of 0.98 . This means that the best fit of our model to observed data suggests that the best predictor of the share of intergovernmental transfers to states is the regional density of population in Mexico.

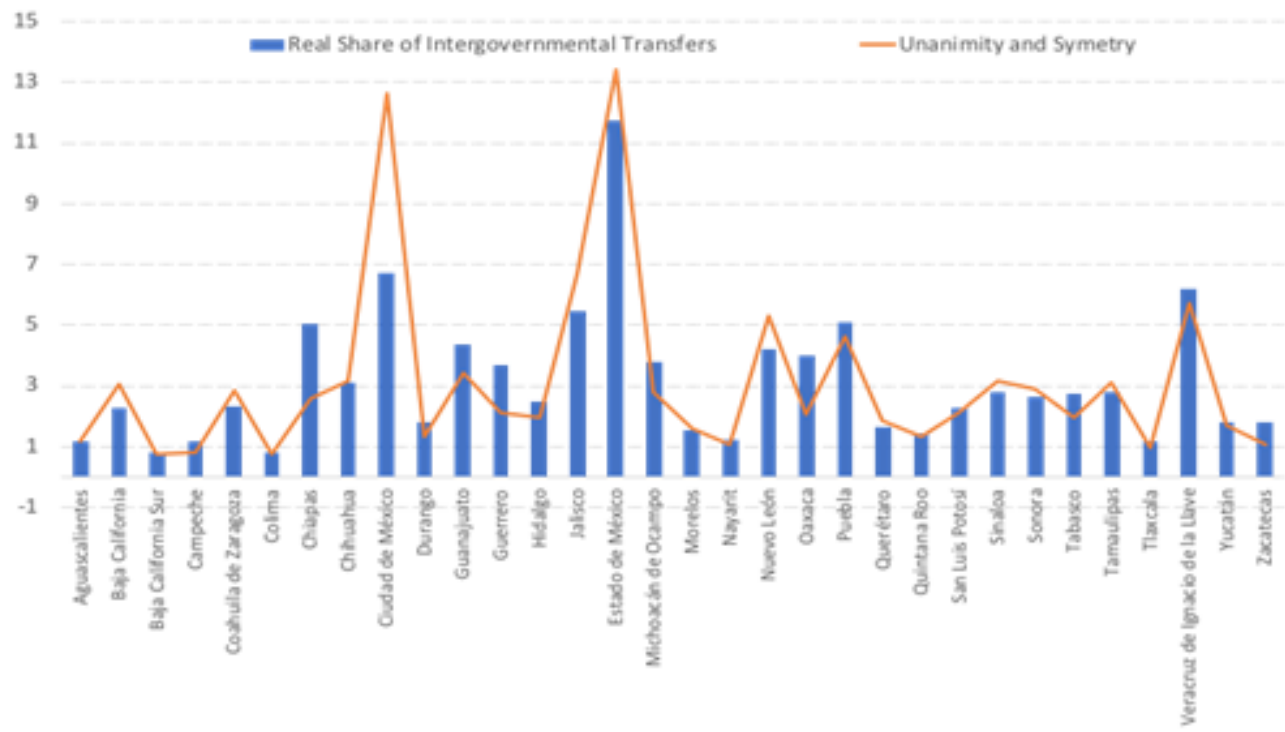

Figure 5. Real and Estimated Shares of Inter-Governmental Transfers by State When Social Weights Reflect Principles of Unanimity and Symmetry

Table 2 shows the main winners and losers from a change in the allocation of intergovernmental transfers from the current system towards using social weights in the social welfare function satisfying the unanimity and symmetry properties in which all households have the same marginal social utility are Ciudad de Mexico, Estado de Mexico, Jalisco, and Nuevo Leon with gains in percentage points of $5.871 .63,1.20$, and 1.11 of the total amount of resources devoted to intergovernmental transfers (see table 2). ${ }^{7}$ Clearly, the gains would be concentrated in Ciudad de Mexico and these gains would come to the expense of several states that would receive less intergovernmental transfers. In particular,

\footnotetext{
${ }^{7}$ That is to say, the observed share of intergovernmental transfers received by Ciudad de Mexico in 2014 were $6.74 \%$ while the corresponding share of intergovernmental transfers received by Ciudad de Mexico if social weights satisfy the properties of unanimity and symmetry is $12.61 \%$. this represents a gain of 5.87 in percentage points of the total amount of resources devoted to intergovernmental transfers.
} 
the states that would lose intergovernmental transfers would be Chiapas (with a loss of 2.45 percentage points), Oaxaca (with a loss of 1.98 percentage points), Guerrero (with a loss of 1.58 percentage points) and Michoacan (with a loss of 0.99 percentage points), Guanajuanto (with a loss of 0.92 percentage points) and Tabasco (with a loss of 0.78 percentage points).

Table 2. Winners and Loser from the Current System Towards a Change of Social Weights Satisfying Unanimity and Symmetry Treatment from the Central Government

\begin{tabular}{|c|c|c|c|c|c|c|c|}
\hline State & $\begin{array}{c}\text { Social Weights } \\
\text { with Unanimity } \\
\text { and Symmetry }\end{array}$ & $\begin{array}{c}\text { Real Share } \\
\text { of Intergov } \\
\text { Transfers }\end{array}$ & Gain & State & $\begin{array}{c}\text { Social Weights } \\
\text { with Unanimity } \\
\text { and Symmetry }\end{array}$ & $\begin{array}{c}\text { Real Share Intergov } \\
\text { of Inansfers } \\
\text { Trant }\end{array}$ & $\begin{array}{c}\text { Loss } \\
\text { Ciudad de México }\end{array}$ \\
\hline Estado de México & 12.61 & 6.74 & 5.87 & Chiapas & 2.60 & 5.05 & -2.45 \\
\hline Jalisco & 6.65 & 11.73 & 1.68 & Oaxaca & 2.07 & 3.98 & -1.91 \\
\hline Nuevo León & 5.31 & 4.45 & 1.20 & Guerrero & 2.13 & 3.70 & -1.58 \\
\hline Baja California & 3.08 & 2.29 & 0.79 & Guanajuato & 3.43 & 3.77 & -0.99 \\
\hline Coahuila & 2.82 & 2.34 & 0.48 & Tabasco & 1.97 & 2.35 & -0.92 \\
\hline
\end{tabular}

Figure 7 shows the observed shares of inter-governmental transfers and the estimated shares of intergovernmental transfers for the case in which policy makers are concerned with the regional inequality in the distribution of state income. In this case, our estimates of the shares of inter-governmental transfers are given by $s_{i P}^{*}=\frac{\frac{N_{i} \beta_{i}}{e_{i}}}{\sum_{i=1}^{I} \frac{N_{i} \beta_{i}}{e_{i}}}$ (see table 1). Figure 7 shows several aspects that are relevant to point out: first, the estimates from the theoretical model are undoubtedly different to the observed intergovernmental transfers received by states in 2014. The average estimated share of intergovernmental transfers to be received by state governments for the case social weights reflect concerns over inequality of income is 3.30 and the variance of the distribution is 0.83 . In contrast, the observed share of transfers received by state governments is 3.32 and the variance of the distribution is 5.01 .

The difference in the variance between the observed and estimated shares means that a change towards using social weights determined according to a concern of policy makers with the regional inequality of income leads to a more equitable allocation of intergovernmental transfers across regions. Second, the correlation between the real shares and the estimates assuming weights of the social welfare reflect concerns about the regional inequality in the distribution of income is 0.24 .

What this means, is that policy makers in Mexico does not seem to incorporate (in a significant way) the regional inequality in the distribution of state income in the allocation of inter-governmental transfers to state governments. If policy makers were to consider the regional inequality of income the observed transfers would have less variability over localities. 


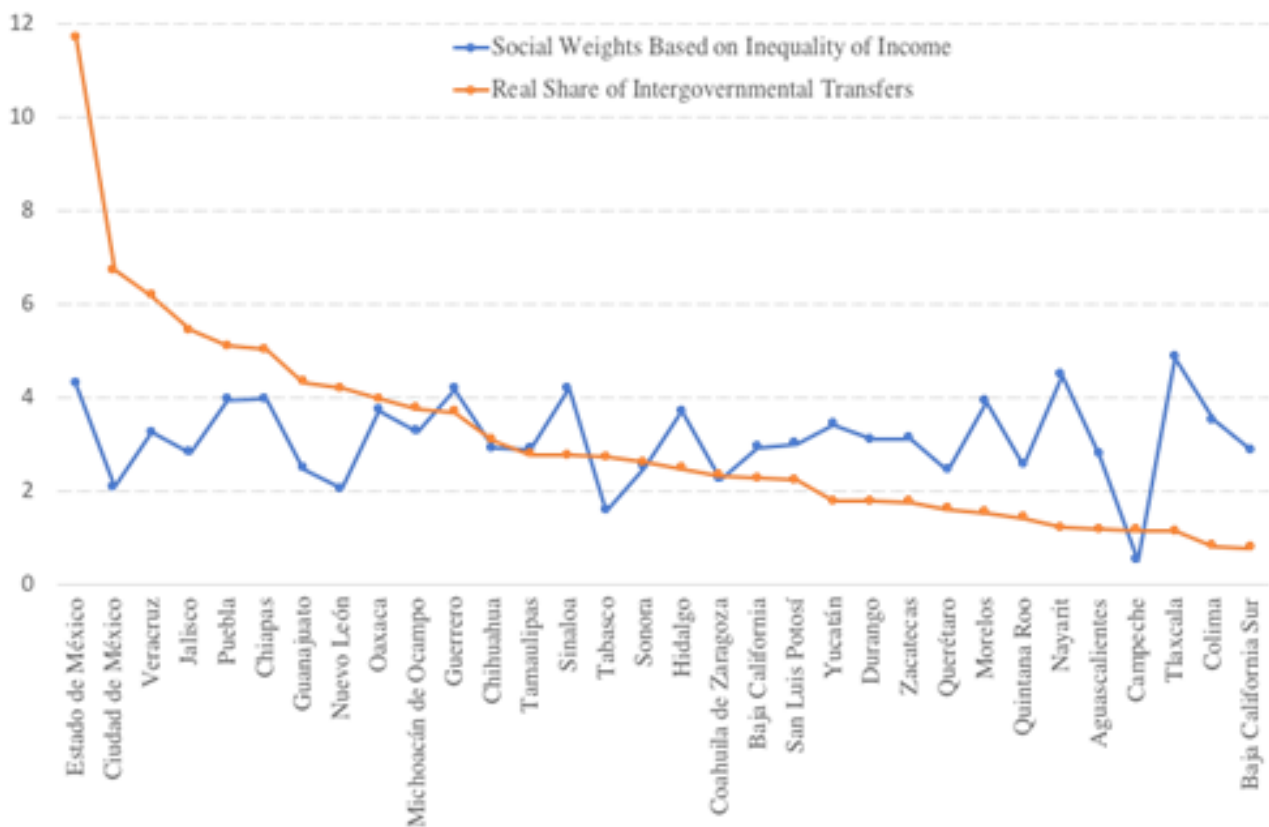

Figure 6. Real and Estimated Shares of Inter-Governmental Transfers by State When Social Weights Reflect Concerns About the Regional Inequality of Income

Table 3 shows the main winners and losers from a change in the allocation of intergovernmental transfers from the current system towards using social weights in the social welfare function according to a concern of policy makers with the regional inequality of income. The states with the gains in the allocation of intergovernmental transfers are Tlaxcala, Nayarit, Colima, Morelos, Baja California Sur and Yucatan with gains in percentage points, respectively, of $3.72,3.28,2.70,2.39,2.09$ and 1.63 of the total amount of resources for intergovernmental transfers.

Table 3. Winners and Losers from a Change from the Current System Towards Social Weights Considering the Regional Inequality of Income

\begin{tabular}{|c|c|c|c|c|c|c|c|}
\hline State & $\begin{array}{c}\text { Social Weights } \\
\text { Based on Inequality } \\
\text { of Income }\end{array}$ & $\begin{array}{c}\text { Real Share } \\
\text { of Intergov } \\
\text { Transfers }\end{array}$ & Gain & State & $\begin{array}{c}\text { Social Weights } \\
\text { Based on Inequality } \\
\text { of Income }\end{array}$ & $\begin{array}{c}\text { Real Share } \\
\text { of Intergov } \\
\text { Transfers }\end{array}$ & Loss \\
\hline Tlaxcala & 4.87 & 1.15 & 3.72 & $\begin{array}{l}\text { Estado de } \\
\text { México }\end{array}$ & 4.31 & 11.73 & -7.42 \\
\hline Nayarit & 4.50 & 1.22 & 3.28 & $\begin{array}{l}\text { Ciudad de } \\
\text { México }\end{array}$ & 2.09 & 6.74 & -4.65 \\
\hline Colima & 3.52 & 0.83 & 2.70 & Veracruz & 3.27 & 6.19 & -2.92 \\
\hline Morelos & 3.93 & 1.54 & 2.39 & Jalisco & 2.83 & 5.45 & -2.62 \\
\hline $\begin{array}{c}\text { Baja California } \\
\text { Sur }\end{array}$ & 2.89 & 0.80 & 2.09 & Nuevo León & 2.07 & 4.21 & -2.14 \\
\hline Yucatán & 3.43 & 1.80 & 1.63 & Guanajuato & 2.50 & 4.35 & -1.85 \\
\hline
\end{tabular}

The states that would lose from a change towards using social weights in a social welfare function according to a concern of policy makers with the regional inequality of income are Estado de Mexico (with a loss of 7.42 percentage points), Ciudad de Mexico (with a loss of 4.65 percentage points), Veracruz (with a loss of 3.27 percentage points), Jalisco (with a loss of 2.67 percentage points), Nuevo León (with a loss of 2.14 percentage points), and Guanajuato (with a loss of 1.85 percentage points).

Figure 8 shows the observed shares of inter-governmental transfers and the estimated shares of intergovernmental transfers for the case in which policy makers are concerned with the regional heterogeneity of preferences. That is to say, policy makers could assign weights that are positively related to localities with high marginal social benefits from local public goods and low marginal social costs from taxation. 


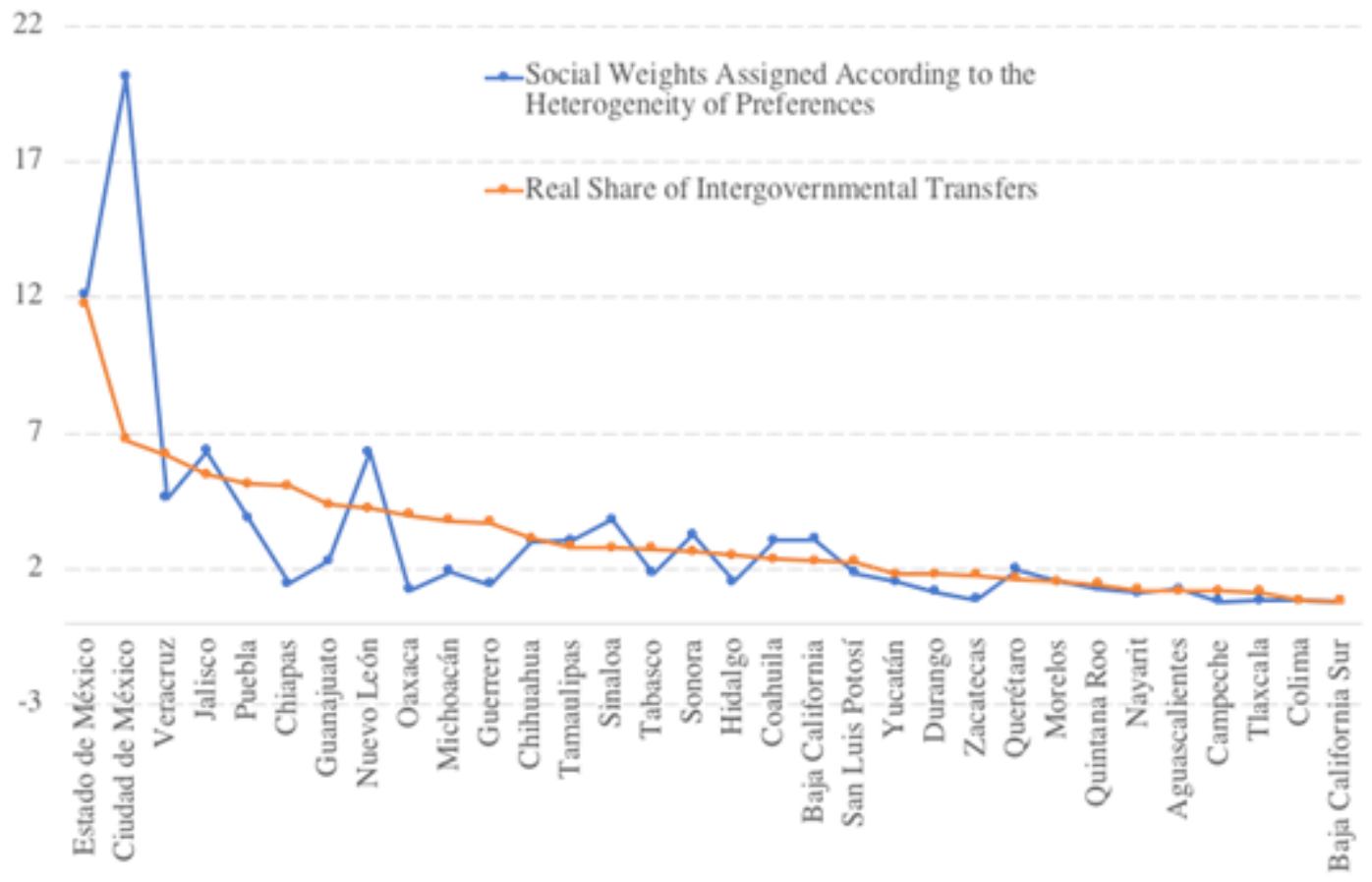

Figure 7. Real and Estimated Shares of Inter-Governmental Transfers by State When Social Weights Reflect Concerns About the Regional Heterogeneity of Preferences

In this case, our estimates of the shares of inter-governmental transfers are given by $s_{i \beta}^{*}=\frac{N_{i}\left(\beta_{i}\right)^{2}}{\sum_{i=1}^{I} N_{i}\left(\beta_{i}\right)^{2}}$ (see table 1$)$. Figure 8 also shows that the distribution of intergovernmental transfers leads to more variance in the regional distribution of intergovernmental transfers and concentrates the gains in Ciudad de Mexico. The average share of transfers received by state governments is 2.85 and the variance of the distribution is 14.77 and the observed share of transfers received by state governments is 3.32 and the variance of the distribution is 5.01. Furthermore, the correlation between the real shares and the estimates (assuming weights of the social welfare reflect concerns about the regional inequality in the distribution of income) is 0.72 .

Table 4. Winners and Loser from the Current System Towards a Change of Social Weights Considering Regional Heterogeneity

\begin{tabular}{|c|c|c|c|c|c|c|c|}
\hline State & $\begin{array}{c}\text { Shares of } \\
\text { Inter-Gov } \\
\text { Transfers Under } \\
\text { Heterogeneity of } \\
\text { Preferences }\end{array}$ & $\begin{array}{c}\text { Real Share of } \\
\text { Intergovernmental } \\
\text { Transfers }\end{array}$ & Gain & State & $\begin{array}{c}\text { Shares of } \\
\text { Inter-Gov } \\
\text { Transfers Under } \\
\text { Heterogeneity of } \\
\text { Preferences }\end{array}$ & $\begin{array}{c}\text { Real Share of } \\
\text { Intergovernmental } \\
\text { Transfers }\end{array}$ & $\begin{array}{c}\text { Loss } \\
\text { Ciudad de } \\
\text { México }\end{array}$ \\
\hline Nuevo León & 6.12 & 6.74 & 13.38 & Chiapas & 1.46 & 5.05 & -3.59 \\
\hline Sinaloa & 3.82 & 4.21 & 2.10 & Oaxaca & 1.21 & 3.98 & -2.78 \\
\hline Jalisco & 6.32 & 2.78 & 1.04 & Guerrero & 1.43 & 3.70 & -2.28 \\
\hline Baja California & 3.08 & 5.45 & 0.87 & Guanajuato & 2.29 & 4.35 & -2.06 \\
\hline Coahuila & 3.05 & 2.29 & 0.79 & Michoacán & 1.90 & 3.77 & -1.87 \\
\hline
\end{tabular}




\section{Conclusion}

Modern economies use intergovernmental transfers to help finance important goods and services provided by subnational governments such as education, health services, infrastructure and anti-poverty programs. The normative literature of public economics has emphasized that intergovernmental transfers should be designed to alleviate problems of regional inequality and inefficiency in the allocation of resources. The literature on optimal taxation and spending has also pointed out that resources should be allocated to the highest economic returns and therefore the regional heterogeneity of preferences of individuals for local public spending should also be a principle of policy design in intergovernmental transfers.

In this paper we develop an optimal theory of intergovernmental transfers which provides specific rules for shares of resources of intergovernmental transfers to be assigned to state governments in Mexico. Based on this theory, we develop a simulation analysis that provides estimates about the optimal shares of resources to be allocated to state governments assuming that policy makers might have objectives such as minimizing the regional inequality of income and maximizing social welfare by matching local public spending with the heterogeneous regional preferences of individuals.

Our analysis provides interesting insights about the regional distribution of intergovernmental transfers in Mexico: the best fit of our model to observed data suggests that policy makers could use a social welfare function that satisfies the properties of anonymity and symmetry (all states receive the same social weight in the social welfare function). Our estimates also suggest that the best predictor of the share of intergovernmental transfers is the density of population in Mexico. This has the important implication that policy makers in Mexico do not fully incorporate the heterogeneity of preferences for goods and services provided by subnational governments and the regional inequality of income in the design of intergovernmental transfers.

However, our model suggests that incorporating these objectives of policy would lead to a different allocation of intergovernmental transfers that would represent a Pareto improvement in the allocation of public resources in the Mexican economy. In this paper, we provide estimates of optimal shares of intergovernmental transfers for state governments that take into account the heterogeneity of preferences for goods and services and the regional inequality of income in the design of intergovernmental transfers.

Our analysis also represents a proposal for policy reform in the allocation of intergovernmental transfers. In this paper we have assumed that policy makers want to maximize a social welfare function and therefore this paper contributes in pointing out feasible policy reforms that could lead to Pareto improvements. However, politicians and bureaucrats (who are in charge of the design and implementation of policy) might not seek to design policy to maximize the society's welfare but to benefit groups of interest or to maximize votes in elections. In that sense, the policy prescriptions described in this paper might not be aligned with political realities and electoral incentives. An interesting avenue for future research is to extend this analysis considering a modern political economy view that could also point out towards political feasibility in policy design. 


\section{Referencias}

Atkinson, A. B. and J. E. Stiglitz (1972). "The structure of indirect taxation and economic efficiency." Journal of Public Economics 1(1): 97-119.

Atkinson, A. B. and J. E. Stiglitz (1976). "The design of tax structure: Direct versus indirect taxation and economic efficiency." Journal of Public Economics 6(1): 55-75.

Besley, T., and S. Coate. (2003). "Centralized versus decentralized provision of local public goods: a political economy approach.", Journal of Public Economics, 87: 2611-2637

Brennan, G., and Buchanan, J., (1980). "The power to tax: analytical foundations of a fiscal constitution, Cambridge; New York:Cambridge University Press.

Centro de Estudios de las Finanzas Publicas, (2017), "Criterios que se utilizan para la asignación presupuestal a entidades federativas y municipios en la Ley de Coordinación Fiscal". 1-54.

Bahl, R., J Boex, y J. Martinez-Vazquez, (2001), "The Design and Implementation of Intergovernmental Transfers", International Studies Program, pp:1-25.

Boadway, R. (2007) Intergovernmental redistributive Transfers: efficieny and equity. In: Boadway, R.A. and Shah, A., Eds., Intergovernmental Transfers, Principles and Practice, The World Bank, Washington DC, 317-338.

Boadway, R. and Shah, A. (2007) Intergovernmental Fiscal Transfers: Theory and Practice. The World Bank, Washington DC.

Caceres, R.L. and S.F. Seninger (1980). "Redes interregionales, estructuras jerarquicas y fuga de la riqueza en centroamérica: un análisis de cadena de Markov". El Trimestre Económico Vol. 49, 195(3), 623645.

Caceres, R.L. (1995), "Las disparidades nacionales y la integración subregional", Comercio Exterior Vol. 45, 99-105.

Ferris, J.M. (1983).Demands for public spending: An attitudinal approach. Public Choice 40: 135-154. https://doi.org/10.1007/BF00118516

Hankla, C. J. Martinez-Vazquez, and R.A. Ponce Rodriguez, (2019), Local accountability and national coordination in fiscal federalism, Edward and Elgard Publishing. London, UK.

Hettich, Walter, and Stanley L. Winer. (2005). Democratic choice and taxation: a theoretical and empirical analysis. New York: Cambridge University Press.

Holsey C.M. and T. Borcherding., (1997), Why does government's share of national income grow? An assessment of the recent literature on the U.S. experience, in Mueller D., Perspectives on Public Choice, A Handbook, Cambridge University Press.

Lockwood, B. 2008. Voting, lobbying and the decentralization theorem, Economics Politics, 20(3): 416431. - 2015. The political economy of decentralization, in: E. Ahmad, and G. Brosio (eds), Handbook of Multilevel Finance, Edward Elgar Publishing, pp. 33-60.

Meltzer, A. H. and Richard, S. F. (1981) . A Rational Theory of the Size of Government, "Journal of Political Economy 89: 914 - 927.

Ponce-Rodriguez, R.A and J.C. Medina- Guirado. (2018). Fiscal Institutions and the Size and InterRegional Distribution of Public Redistribution, Ensayos, Revista de Economía 37(1), 1-42.

Ponce-Rodriguez, R.A., C. Hankla, J., Martinez Vazquez and E. Heredia-Ortiz, (2018), Rethinking the Political Economy of Decentralization How Elections and Parties Shape the Provision of Local Public Goods, Publius: the Journal of federalism, Vol. 48, No. 4, 523-558.

Rao, M.G. (2007) Resolving Fiscal Imbalances: Issues in Tax Sharing. In: Boadway, R.A. and Shah, A., Eds., Intergo- vernmental Transfers, Principles and Practice, The World Bank, Washington DC, 317-338.

Saez, Emmanuel, and Stefanie Stantcheva. 2016. "Generalized Social Marginal Welfare Weights for Optimal Tax Theory.. American Economic Review, 106 (1): 24-45.

Smart, M., (1998), "Taxation and Deadweight Loss in a System of Intergovernmental Transfers" Canadian Journal of Economics 31, pp. 189-206.

Ter-Minassian, T. (1997), "Fiscal Federalism in Theory and Practice", Washington: The International Monetary Fund.

Theodore C. Bergstrom, Daniel L. Rubinfeld and Perry Shapiro. (1982). Micro-Based Estimates of Demand Functions for Local School Expenditures. Econometrica 50(5), 1183-1205.

World Bank. (2019). Mexico: Reforming Intergovernmental Transfers to More Effectively Advance Their Policy Objectives (English). Washington, D.C. : World Bank Group. 


\section{Appendix.}

Proposition 1. The optimal allocation of inter-governmental transfers to subnational government in locality $i$ is given by

\section{Proof.}

$$
T_{i}^{*}=\Phi_{i} N_{i} \beta_{i}\left\{\frac{\sum_{i=1}^{I} N_{i} e_{i}}{\sum_{i=1}^{I} \Phi_{i} N_{i} e_{i}}\right\} \quad \forall i
$$

The problem of policy design can be stated as follows:

$$
\delta=\sum_{i=1}^{I} \Phi_{i} N_{i}\left\{e_{i}(1-\tau)+\beta_{i} \ln \left(T_{i}\right)\right\}+\lambda\left\{\tau \sum_{i=1}^{I} N_{i} e_{i}-\sum_{i=1}^{I} T_{i}\right\}
$$

Where $\lambda$ is a Lagrange multiplier. The first order conditions are:

$$
\begin{aligned}
& \frac{\partial \delta}{\partial T_{i}}=\frac{\Phi_{i} N_{i} \beta_{i}}{T_{i}^{*}}-\lambda^{*}=0 \quad \forall T_{i}^{*}>0 \\
& \frac{\partial \delta}{\partial \tau}=-\sum_{i=1}^{I} \Phi_{i} N_{i} e_{i}+\lambda^{*} \sum_{i=1}^{I} N_{i} e_{i}=0 \quad \forall \tau^{*}>0 \\
& \frac{\partial \delta}{\partial \lambda}=\tau^{*} \sum_{i=1}^{I} N_{i} e_{i}-\sum_{i=1}^{I} T_{i}^{*}=0 \quad \forall \lambda^{*}>0
\end{aligned}
$$

Re-arrange the first order conditions to show that

$$
T_{i}^{*}=\Phi_{i} N_{i} \beta_{i}\left\{\frac{\sum_{i=1}^{I} N_{i} e_{i}}{\sum_{i=1}^{I} \Phi_{i} N_{i} e_{i}}\right\} \quad \forall i
$$

Proposition 3. If the allocation of social weights is determined by equity concerns about the inter-regional distribution of income such that

$$
\Phi_{i}=\left\{\begin{array}{cc}
\frac{e_{i \min }}{e_{i}} & \forall e_{i} \geq e_{i m i n} \\
0 & \forall e_{i}<e_{i m i n}
\end{array}\right.
$$

Then the optimal allocation of inter-governmental transfers is denoted by $T_{i P}^{*}$ such that

$$
T_{i P}^{*}=N_{i} \beta_{i}\left\{\frac{E_{f}\left(e_{i}\right)}{e_{i}}\right\} \quad \forall i
$$

And $E_{f}\left(e_{i}\right)=\sum_{i=1}^{I} f_{i} e_{i}$ is a weighted average of per capita income in locality $i$, and $f_{i}$ is the density of population in locality $i$ over the nationwide population such that

$$
f_{i} \in(0,1]: f_{i}=\frac{N_{i}}{\sum_{i=1}^{I} N_{i}} \wedge \sum_{i=1}^{I} f_{i}=1
$$

\section{Proof.}

From proposition 1, the optimal level of inter-governmental transfers is given by:

$$
T_{i}^{*}=\Phi_{i} N_{i} \beta_{i}\left\{\frac{\sum_{i=1}^{I} N_{i} e_{i}}{\sum_{i=1}^{I} \Phi_{i} N_{i} e_{i}}\right\} \quad \forall i
$$

If priorities on policy are determined social weights that reflect a concern over the interregional inequality of income such that

$$
\Phi_{i}=\left\{\begin{array}{cc}
\frac{e_{i \min }}{e_{i}} & \forall e_{i} \geq e_{i m i n} \\
0 & \forall e_{i}<e_{i m i n}
\end{array}\right.
$$

Then use $\Phi_{i}=\frac{e_{i \min }}{e_{i}} \forall i$ to show $T_{i P}^{*}$ is given by:

$$
\begin{array}{ll}
T_{i P}^{*}= & \frac{e_{i \min }}{e_{i}} N_{i} \beta_{i}\left\{\frac{\sum_{i=1}^{I} N_{i} e_{i}}{\sum_{i=1}^{I}\left\{\frac{e_{i m i n}}{e_{i}}\right\} N_{i} e_{i}}\right\} \quad \forall i \\
\Rightarrow \quad T_{i P}^{*}=\frac{N_{i} \beta_{i}}{e_{i}}\left\{\frac{\sum_{i=1}^{I} N_{i} e_{i}}{\sum_{i=1}^{I} N_{i}}\right\} \quad \forall i &
\end{array}
$$

We define $f_{i}$ as the density of population in locality i over the nationwide population such that

$$
f_{i} \in(0,1]: f_{i}=\frac{N_{i}}{\sum_{i=1}^{I} N_{i}} \wedge \sum_{i=1}^{I} f_{i}=1
$$

And define the weighted average of per capita income in locality i, by $E_{f}\left(e_{i}\right)$, where

$$
E_{f}\left(e_{i}\right)=\sum_{i=1}^{I} f_{i} e_{i}
$$

Then express $T_{i P}^{*}$ as follows:

$$
T_{i P}^{*}=N_{i} \beta_{i}\left\{\frac{E_{f}\left(e_{i}\right)}{e_{i}}\right\} \quad \forall i
$$


Proposition 5. If the allocation of social weights is determined by an Inter-Regional Paretian distribution of preferences given by

$$
\Phi_{i}=\left\{\begin{array}{cc}
\frac{\beta_{i}}{\beta_{i_{\max }}} & \forall \beta_{i} \leq \beta_{i_{\max }} \\
0 & \forall \beta_{i}>\beta_{i_{\max }}
\end{array}\right.
$$

Then the optimal allocation of inter-governmental transfers is denoted by $T_{i \beta}^{*}$ such that

$$
T_{i \beta}^{*}=N_{i} \beta_{i}\left\{\frac{\beta_{i}}{E_{h}\left(\beta_{i}\right)}\right\} \quad \forall i
$$

Where $E_{h}\left(\beta_{i}\right)=\sum_{i=1}^{I} h_{i} \beta_{i}$, is the nationwide weighted average of the parameter of intensity of preferences $\beta_{i}$ and

$$
h_{i}\left(e_{i}\right) \in(0,1]: h_{i}\left(e_{i}\right)=\frac{N_{i} e_{i}}{\sum_{i=1}^{I} N_{i} e_{i}}
$$

Proof.

From proposition 1, the optimal level of inter-governmental transfers is given by:

$$
T_{i}^{*}=T_{i}^{*}=\Phi_{i} N_{i} \beta_{i}\left\{\frac{\sum_{i=1}^{I} N_{i} e_{i}}{\sum_{i=1}^{I} \Phi_{i} N_{i} e_{i}}\right\} \quad \forall i
$$

If priorities on policy are determined social weights that reflect a concern over the interregional distribution of preferences for local public spending such that

$$
\Phi_{i}=\left\{\begin{array}{cc}
\frac{\beta_{i}}{\beta_{i_{\max }}} & \forall \beta_{i} \leq \beta_{i_{\max }} \\
0 & \forall \beta_{i}>\beta_{i_{\max }}
\end{array}\right.
$$

Then use $\Phi_{i}=\frac{\beta_{i}}{E_{\max }\left(\beta_{i}\right)} \forall i$ to show $T_{i \beta}^{*}$ is given by:

$$
T_{i \beta}^{*}=\frac{\beta_{i}}{\beta_{i \max }} N_{i} \beta_{i}\left\{\frac{\sum_{i=1}^{I} N_{i} e_{i}}{\sum_{i=1}^{I}\left\{\frac{\beta_{i}}{\beta_{i} \text { max }}\right\} N_{i} e_{i}}\right\} \quad \forall i
$$

Equivalent to

$$
T_{i \beta}^{*}=\beta_{i} N_{i} \beta_{i}\left\{\frac{\sum_{i=1}^{I} N_{i} e_{i}}{\sum_{i=1}^{I} \beta_{i} N_{i} e_{i}}\right\} \quad \forall i
$$

Note that we can define $h_{i}\left(e_{i}\right)$ as the share of income in locality i over the nationwide income, in the following way:

$$
h_{i}\left(e_{i}\right) \in(0,1]: h_{i}\left(e_{i}\right)=\frac{N_{i} e_{i}}{\sum_{i=1}^{I} N_{i} e_{i}} \wedge \sum_{i=1}^{I} h_{i}\left(e_{i}\right)=1
$$

And define $E_{h}\left(\beta_{i}\right)$ as the nationwide weighted average of the parameter of intensity of preferences $\beta_{i}$ such that.

$$
E_{h}\left(\beta_{i}\right)=\sum_{i=1}^{I} h_{i} \beta_{i}
$$

Use the former condition in $\mathrm{T}_{i \beta}^{*}$ toshow:

$$
T_{i \beta}^{*}=N_{i} \beta_{i}\left\{\frac{\beta_{i}}{E_{h}\left(\beta_{i}\right)}\right\} \quad \forall i
$$


Table 5. Shares of Intergovernmental Transfers, Estimates of Simulation Analysis

\begin{tabular}{|c|c|c|c|c|}
\hline Entidad & $\begin{array}{c}\text { Real (Observed) } \\
\text { Share of } \\
\text { Intergovernmental } \\
\text { Transfers }\end{array}$ & $\begin{array}{c}\text { Social Weights } \\
\text { Considering } \\
\text { Unanimity } \\
\text { and Symmetry }\end{array}$ & $\begin{array}{l}\text { Social Weights } \\
\text { Considering } \\
\text { Inequality } \\
\text { of Income }\end{array}$ & $\begin{array}{c}\text { Social Weights } \\
\text { Considering } \\
\text { Heterogeneity } \\
\text { of Preferences }\end{array}$ \\
\hline Aguascalientes & 1,19 & 1,18 & 2,80 & 1,24 \\
\hline Baja California & 2,29 & 3,08 & 2,93 & 3,08 \\
\hline Baja California Sur & 0,80 & 0,74 & 2,89 & 0,81 \\
\hline Campeche & 1,16 & 0,80 & 0,52 & 0,79 \\
\hline Coahuila & 2,34 & 2,82 & 2,26 & 3,05 \\
\hline Colima & 0,83 & 0,73 & 3,52 & 0,84 \\
\hline Chiapas & 5,05 & 2,60 & 3,98 & 1,46 \\
\hline Chihuahua & 3,10 & 3,15 & 2,92 & 3,03 \\
\hline Ciudad de México & 6,74 & 12,61 & 2,09 & 20,12 \\
\hline Durango & 1,80 & 1,33 & 3,11 & 1,14 \\
\hline Guanajuato & 4,35 & 3,43 & 2,50 & 2,29 \\
\hline Guerrero & 3,70 & 2,13 & 4,19 & 1,43 \\
\hline Hidalgo & 2,49 & 1,97 & 3,71 & 1,53 \\
\hline Jalisco & 5,45 & 6,65 & 2,83 & 6,32 \\
\hline Edo. de México & 11,73 & 13,41 & 4,31 & 12,10 \\
\hline Michoacán & 3,77 & 2,78 & 3,28 & 1,90 \\
\hline Morelos & 1,54 & 1,60 & 3,93 & 1,51 \\
\hline Nayarit & 1,22 & 1,09 & 4,50 & 1,10 \\
\hline Nuevo León & 4,21 & 5,31 & 2,07 & 6,30 \\
\hline Oaxaca & 3,98 & 2,07 & 3,74 & 1,21 \\
\hline Puebla & 5,11 & 4,60 & 3,96 & 3,86 \\
\hline Querétaro & 1,63 & 1,87 & 2,44 & 1,98 \\
\hline Quintana Roo & 1,43 & 1,32 & 2,56 & 1,28 \\
\hline San Luis Potosí & 2,25 & 2,11 & 3,02 & 1,83 \\
\hline Sinaloa & 2,78 & 3,17 & 4,20 & 3,82 \\
\hline Sonora & 2,62 & 2,90 & 2,53 & 3,26 \\
\hline Tabasco & 2,74 & 1,97 & 1,58 & 1,84 \\
\hline Tamaulipas & 2,80 & 3,09 & 2,91 & 3,05 \\
\hline Tlaxcala & 1,15 & 0,98 & 4,87 & 0,85 \\
\hline Veracruz & 6,19 & 5,72 & 3,27 & 4,59 \\
\hline Yucatán & 1,80 & 1,70 & 3,43 & 1,54 \\
\hline Zacatecas & 1,78 & 1,09 & 3,14 & 0,85 \\
\hline Average & 3,33 & 3,14 & 3,31 & 2,85 \\
\hline Variance & 5,02 & 8,84 & 0,83 & 14,78 \\
\hline
\end{tabular}

